
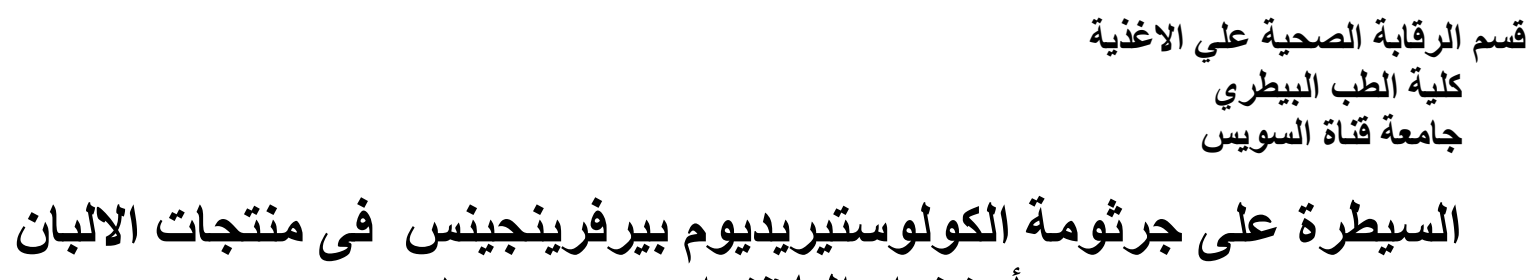

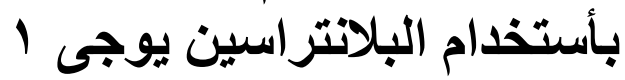

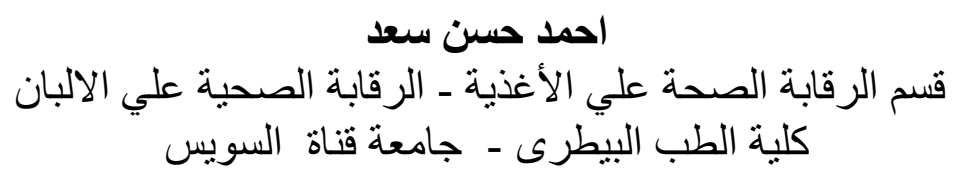

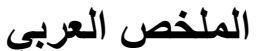

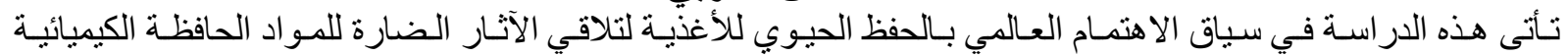

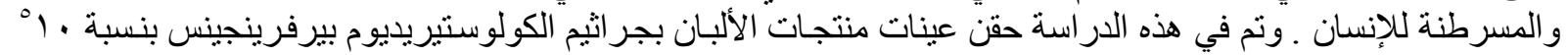

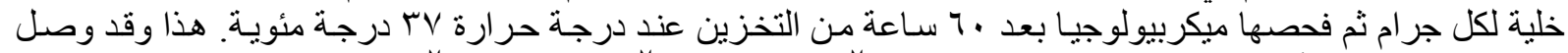

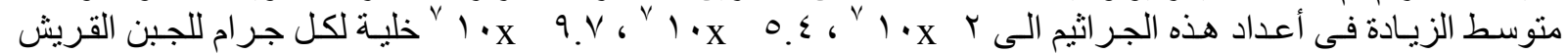

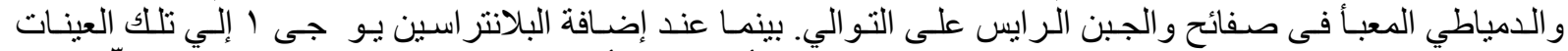

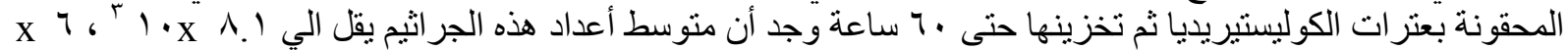

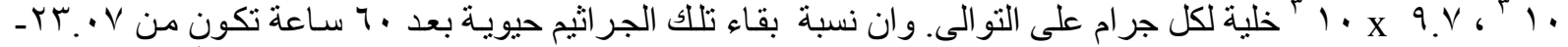

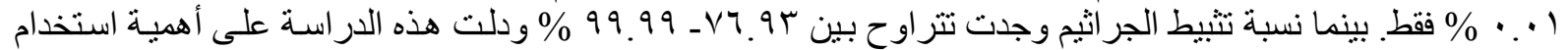

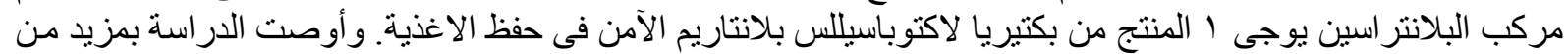

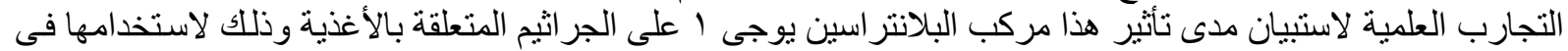

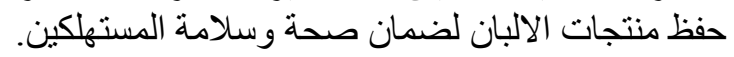

\title{
Control of Clostridium perfringens ATCC13700 in Dairy Products Using Bacteriocin Plantaricin UG1
}

\author{
Ahmed H. Saad \\ Dept. of Food Hygiene \& Control, Faculty of Vet. Med., Suez Canal University, Egypt
}

Abstract

Controlling of Clostridium perfringens ATCC13700 using bacteriocin plantaricin UG1 in vitro and some dairy products was studied. The mean viable cells counts of $\mathrm{Cl}$. perfringens significantly increased $(P<0.05)$ from $10^{5}$ to $10^{8}-10^{9} \mathrm{cfu} / \mathrm{g}$ in all control samples, meanwhile the counts significantly decreased $(P<0.05)$ from $10^{5}$ to $0 \mathrm{cfu} / \mathrm{g}$ in bacteriocin treated brain heart infusion and cooked meat broths. Addition of partially purified plantaricin UG1 to kareish, canned domita and Ras chesses resulted in a significant decline of viable $\mathrm{Cl}$. perfringens cell from $10^{5}$ to $6.0 \times 10^{3}-9.7 \times 10^{3} \mathrm{cfu} / \mathrm{g}$ within $60 \mathrm{hs}$ storage. Consequently, the percentage values of inactivated spores ranged from 99.99 to $76.93 \%$ in all treated dairy samples within $60 \mathrm{hs}$ storage. Although the inhibitory effect of bacteriocin plantaricin UG1 against $\mathrm{Cl}$. perfringens in dairy samples was confirmed in this study, more investigation may be required for clarifying the use of bacteriocin plantaricin UG1 as a natural bio-preservative to control food-borne pathogens in dairy products. 


\section{Introduction}

Clostridium perfringens is a gram-positive, non motile spore forming anaerobic rode. This strain is widely distributed in the nature which exists in soil, sewage, stool and intestine of animal and humans (Steele and Wright, 2001). It is able to produce spore which is capable of surviving in the ultra heat processed dairy foods. Surviving spore may require heat to initiate germination and this is proved by cooking when raw milk is already contaminated spores.

$C l$. perfringens has been isolated from dairy products and its presence could be attributed to contamination of raw milk used in production because its spores, being heat resistant, and would not be destroyed during processing (Sinha and Sinha, 1986). $\mathrm{Cl}$. perfringens food poisoning is common by eating foods stored in large quantities at room temperature in schools, camps and buffets (Martel et al., 2004). The symptoms including watery diarrhea, abdominal pain and gas are attributed to enterotoxin produced by the organism in the intestine (Teo and Tan, 2005). This enterotoxin causes also necrotic enteritis in humans (Wise and Siragusa, 2005).

One of the traditional methods used for preservation of the milk and dairy product for human against bacteria is the addition of chemical preservatives which are harmful .Hence, inhibition of pathogens in foods by a safe lactic acid bacterium or its metabolites is a matter of interest. Bacteriocin plantaricin UG1 produced by Lactobacillus plantarum UG1 isolated from dry sausage inhibited some food borne pathogens including $\mathrm{Cl}$. perfringens in vitro (Enan, 2006b). Plantaricin UG1 was active against clostridia at acidic and neutral pH values (4-7) and over a temperature range from $0-90^{\circ} \mathrm{C}$. (Enan et al., 2004).

Little literatures were published concerning the inhibition of clostridia in dairy products using bacteriocin of Lactobacillus plantarum. Therefore, the present work was undertaken to study the inhibition of $\mathrm{Cl}$. perfringens using Plantaricin UG1 in culture media and some dairy samples.

\section{Materials and Methods}

\section{Strains and Dairy samples}

Cl. Perfringens ATCC 13700, Lactobacillius plantarum UG1 and plantaricin UG1, were obtained from Department of Food Technology and Applied Biological Sciences, University of Gent, Belgium. L. Plantrum UG1, the producer of plantaricin UG1, was maintained at $-20^{\circ} \mathrm{C}$ in De Man Rogosa and Sharp medium plus 20\% glycerol (De-Man et al., 1960), and then propagated in MRS broth. Cl. perfringens ATCC 13700 spores were 
maintained as frozen stock in glass beads at $-20^{\circ} \mathrm{C}$. Few glass beads were suspended in cooked meat broth (Difco), heated at $80^{\circ} \mathrm{C}$ for $15 \mathrm{~min}$ to stimulate spore germination and incubated at $37^{\circ} \mathrm{C}$ for 48 hours. Cells were then subcultured every 48 hour in cooked meat broth. Samples of canned soft (damiatta), kareish and hard cheeses were minced in separate sterile food processor (Ts/12/Omas/Uk). 100g portions from each sample were placed aseptically in sterile plastic bags until used. Brain heart infusion broth (Difco) and cooked meat broth samples (Difco) were added into $250 \mathrm{ml}$ screw capped bottles (100 $\mathrm{ml}$ for each) and autoclaved.

\section{Preparation of Plantaricin UG1}

L. plantarium UG1 was grown in MRS broth for $16 \mathrm{~h}$ at $30^{\circ} \mathrm{C}$. Cell free supernatant was obtained by centrifuging the culture $\left(10000 \mathrm{Xg}\right.$ for $10 \mathrm{~min}$ at $\left.4^{\circ} \mathrm{C}\right)$. The $\mathrm{pH}$ value of cell free supernatant was adjusted at 6.5 and subjected to ammonium sulphate precipitation as described previously (Bhunia et al., 1988). The ammonium sulphate precipitates (Surface pellicles and pellets) were recovered in $10 \mathrm{~m} \mathrm{M}$ potassium phosphate buffer $\mathrm{pH} 6.5$ and dialyzed against the same buffer for $24 \mathrm{~h}$ at $4^{\circ} \mathrm{C}$ in visking dialysis membrane. This partially purified plantaricin UG1 was sterilized by filtration through cellulose membrane filters (Amicon, $0.45 \mathrm{um}$ ) and was used in the experiments. $1 \mathrm{ml}$ of this partially purified plantaricin UG1 appeared to contain $2020 \mathrm{AU} / \mathrm{ml}$ as assayed previously with $\mathrm{Cl}$. perfringens as the indicator organism (Enan et al., 1996).

\section{Preparation of $\boldsymbol{C l}$. Perfringens spores}

This was performed according to procedure described by Craven and Blankenship, (1985). About 1\% inoculum of $\mathrm{Cl}$. perfringens was inoculated into Ducan-Strong Sporulation medium (Duncan and Strong, 1968). Incubation was carried out at $37^{\circ} \mathrm{C}$ for $24 \mathrm{~h}$ without provisions for anaerobiosis. Spores were harvested by centrifugation at $4^{\circ} \mathrm{C}$ and cleaned by repeated washing with cold deionized water. The cleaned phase dark spores were used in the experiments.

\section{Experimental design}

The dairy samples were tested by inoculating of either brain heart infusion broth or cooked meat broth by cell suspension of the experimental $\mathrm{Cl}$. perfringens strain to give $10^{5} \mathrm{cfu} / \mathrm{ml}$. The above inoculated samples were treated with $40880 \mathrm{AU} / \mathrm{ml}$ partially purified plantaricin UG1 and were shaken again to mix the bacteriocin with inoculated samples. The air was excluded from bags by hand; and from culture media as their boiling during sterilization drive off dissolved oxygen. Control samples were inoculated by $\mathrm{Cl}$. Perfringens 
cells without treatment by bacteriocin plantaricin UG1. Treated and controls plates were incubated at $37^{\circ} \mathrm{C}$ in an anaerobic jar equipped with GasPak $\mathrm{H}_{2}+\mathrm{CO}_{2}$ generator envelops and catalyst as described by the manufacturer's instructions (Oxiod). After appropriate time intervals treated and control plates were taken and analyzed for viable counts of $\mathrm{Cl}$. perfringens as described by Rhodehamel and Harmon (2006).

\section{Challenge Test}

The survival of $\mathrm{Cl}$. perfringens spores in the presence of plantaricin UG1 were tested as follows: A series of test tubes, each containing $1 \mathrm{~g}$ aliquots of solid food suspensions of tested samples, bacteriocin and the controls with containing spore suspension without bacteriocin as prepared previously. Samples and controls were incubated under anaerobic conditions as described previously by Rhodehamel and Harmon (2006) for 60hs. Every $10 \mathrm{hs}$, two tubes (one tube of samples and one tube of controls) were taken and heat shocked by heating at $80^{\circ} \mathrm{C}$ for $15 \mathrm{~min}$. in a thermostatically water bath. The colony forming units of heat shocked samples and controls were determined as described previously (Garcia et al., 2001).

\section{Results}

The effect of the bacteriocin plantaricin UG1 on growth of $C l$. perfringens viable cells in both cooked meat broth and brain heart infusion broth is shown in Table 1. The viable cell population of $\mathrm{Cl}$. perfringens in controls samples was significantly increased $(\mathrm{P}<0.05)$ from $10^{5}$ to $9.8 \times 10^{8} \mathrm{cfu} / \mathrm{ml}$ within $60 \mathrm{hs}$ but it significant decrease $(\mathrm{P}<0.05)$ in both treated broths by bacteriocin plantaricin UG1 from $10^{5}$ to $2.9 \times 10^{3}$ and $8.7 \times 10^{2} \mathrm{cfu} / \mathrm{ml}$ respectively within $24 \mathrm{hs}$. No viable counts of $\mathrm{Cl}$. perfringens were detected in the bacteriocin treated culture media after $60 \mathrm{hs}$ of incubation.

Tale 1

Inhibition of $\boldsymbol{C l}$. perfringens ATCC13700 viable cells using plantaricin UG1 in culture media.

\begin{tabular}{|c|c|c|c|c|}
\hline \multirow{2}{*}{ Time(hour) } & \multicolumn{2}{|c|}{ Cooked meat broth } & \multicolumn{2}{c|}{ Brain heat infusion broth } \\
\cline { 2 - 5 } & Control & Sample & Control & Sample \\
\hline $\mathbf{0}$ & ${ }^{\mathrm{a}} 10^{5}$ & ${ }^{\mathrm{a}} 10^{5}$ & ${ }^{\mathrm{a}} 10^{5}$ & ${ }^{\mathrm{a}} 10^{5}$ \\
\hline $\mathbf{6}$ & ${ }^{\mathrm{a}} 6.9 \times 10^{5}$ & ${ }^{\mathrm{a}} 9.8 \times 10^{4}$ & ${ }^{\mathrm{a}} 5.4 \times 10^{5}$ & ${ }^{\mathrm{a}} 9.8 \times 10^{4}$ \\
\hline $\mathbf{1 2}$ & ${ }^{\mathrm{a}} 2.7 \times 10^{6}$ & ${ }^{\mathrm{a}} 1.8 \times 10^{4}$ & ${ }^{\mathrm{a}} 9.7 \times 10^{5}$ & ${ }^{\mathrm{b}} 2.4 \times 10^{4}$ \\
\hline $\mathbf{1 8}$ & ${ }^{\mathrm{b}} 1.3 \times 10^{7}$ & ${ }^{\mathrm{a}} 0.9 \times 10^{4}$ & ${ }^{\mathrm{b}} 4.3 \times 10^{6}$ & ${ }^{\mathrm{b}} 9.2 \times 10^{3}$ \\
\hline $\mathbf{2 4}$ & ${ }^{\mathrm{b}} 4.5 \times 10^{7}$ & ${ }^{\mathrm{b}} 2.9 \times 10^{3}$ & ${ }^{\mathrm{c}} 1.8 \times 10^{7}$ & ${ }^{\mathrm{b}} 8.7 \times 10^{2}$ \\
\hline $\mathbf{3 6}$ & ${ }^{\mathrm{c}} 5.3 \times 10^{8}$ & ${ }^{\mathrm{b}} 1.0 \times 10^{3}$ & ${ }^{\mathrm{d}} 7.4 \times 10^{8}$ & ${ }^{\mathrm{b}} 2.4 \times 10^{2}$ \\
\hline $\mathbf{4 8}$ & ${ }^{\mathrm{c}} 8.2 \times 10^{8}$ & ${ }^{\mathrm{c}} 1.8 \times 10^{2}$ & ${ }^{\mathrm{d}} 9.9 \times 10^{8}$ & ${ }^{\mathrm{c}} 0.90 \times 10^{2}$ \\
\hline $\mathbf{6 0}$ & ${ }^{\mathrm{c}} 9.8 \times 10^{8}$ & ${ }^{\mathrm{d}} 0$ & ${ }^{\mathrm{d}} 1.7 \times 10^{9}$ & ${ }^{\mathrm{d}} 0$ \\
\hline
\end{tabular}

Means by different superscripts in same column are different $(\mathrm{P}<0.05)$ 
The growth values (cfu/g) of $C l$. perfringens in dairy product samples were shown in Table 2 . $C l$. perfringens could grow in all controls dairy samples and significantly increased $(\mathrm{P}<0.05)$ in their mean values from $10^{5}$ to $5.8 \times 10^{7} \mathrm{cfu} / \mathrm{g}$ within $60 \mathrm{hs}$ of incubation. However, in the bacteriocin plantaricin treated samples, the viable cell count of $\mathrm{Cl}$. perfringens significantly decreased $(\mathrm{P}<0.05)$ gradually reaching $8.1 \times 10^{3} \mathrm{cfu} / \mathrm{g} ; 6.0 \times 10^{3} ; 9.7 \times 10^{3} \mathrm{cfu} / \mathrm{g}$ after $60 \mathrm{hr}$ in kareish cheese, canned damiatta cheese and Ras cheese respectively. No organisms could be detected in the bacteriocin treated samples after further 3 days of storage.

Table 2

Growth of the $C l$. perfringens ATCC 13700 viable cells in dairy product samples after bacteriocin plantaracin UG1 treatment.

\begin{tabular}{|c|c|c|c|c|c|c|}
\hline \multirow{2}{*}{ Time(hour) } & \multicolumn{2}{|c|}{ Kareish cheese } & \multicolumn{2}{c|}{ Canned damiatta cheese } & \multicolumn{2}{c|}{ Ras cheese } \\
\cline { 2 - 7 } & Control & Treated & Control & Treated & Control & Treated \\
\hline \multirow{2}{*}{$\mathbf{0}$} & ${ }^{\mathrm{a}} 10^{5}$ & ${ }^{\mathrm{a}} 10^{5}$ & ${ }^{\mathrm{a}} 10^{5}$ & ${ }^{\mathrm{a}} 10^{5}$ & ${ }^{\mathrm{a}} 10^{5}$ & ${ }^{\mathrm{a}} 10^{5}$ \\
\hline $\mathbf{6}$ & ${ }^{\mathrm{a}} 5.2 \times 10^{5}$ & ${ }^{\mathrm{a}} 1.2 \times 10^{5}$ & ${ }^{\mathrm{a}} 4.0 \times 10^{5}$ & ${ }^{\mathrm{a}} 7.2 \times 10^{4}$ & ${ }^{\mathrm{a}} 4.5 \times 10^{5}$ & ${ }^{\mathrm{a}} 10^{5}$ \\
\hline $\mathbf{1 2}$ & ${ }^{\mathrm{a}} 9.8 \times 10^{5}$ & ${ }^{\mathrm{b}} 8.2 \times 10^{4}$ & ${ }^{\mathrm{a}} 6.8 \times 10^{5}$ & ${ }^{\mathrm{a}} 6.3 \times 10^{4}$ & ${ }^{\mathrm{b}} 9.1 \times 10^{5}$ & ${ }^{\mathrm{a}} 9.2 \times 10^{4}$ \\
\hline $\mathbf{1 8}$ & ${ }^{\mathrm{b}} 1.2 \times 10^{6}$ & ${ }^{\mathrm{b}} 6.8 \times 10^{4}$ & ${ }^{\mathrm{b}} 1.3 \times 10^{6}$ & ${ }^{\mathrm{a}} 5.1 \times 10^{4}$ & ${ }^{\mathrm{b}} 1.1 \times 10^{6}$ & ${ }^{\mathrm{b}} 6.1 \times 10^{4}$ \\
\hline $\mathbf{2 4}$ & ${ }^{\mathrm{b}} 4.6 \times 10^{6}$ & ${ }^{\mathrm{b}} 5.0 \times 10^{4}$ & ${ }^{\mathrm{b}} 4.1 \times 10^{6}$ & ${ }^{\mathrm{a}} 3.9 \times 10^{4}$ & ${ }^{\mathrm{b}} 9.0 \times 10^{6}$ & ${ }^{\mathrm{b}} 4.2 \times 10^{4}$ \\
\hline $\mathbf{4 8}$ & ${ }^{\mathrm{b}} 7.2 \times 10^{6}$ & ${ }^{\mathrm{b}} 3.8 \times 10^{4}$ & ${ }^{\mathrm{c}} 1.2 \times 10^{7}$ & ${ }^{\mathrm{b}} 2.4 \times 10^{4}$ & ${ }^{\mathrm{c}} 1.1 \times 10^{7}$ & ${ }^{\mathrm{B}} 3.5 \times 10^{4}$ \\
\hline $\mathbf{6 0}$ & ${ }^{\mathrm{c}} 1.1 \times 10^{7}$ & ${ }^{\mathrm{b}} 1.3 \times 10^{4}$ & ${ }^{\mathrm{c}} 3.7 \times 10^{7}$ & ${ }^{\mathrm{c}} 8.1 \times 10^{3}$ & ${ }^{\mathrm{c}} 3.6 \times 10^{7}$ & ${ }^{\mathrm{B}} 1.2 \times 10^{4}$ \\
\hline
\end{tabular}

Means by different superscripts in same column are different $(\mathrm{P}<0.05)$

The percentage of survived spores were gradually decreased reaching $0.04 \% ; 0.01 \%$; $0.02 \%$ in kareish cheese; canned damiatta cheese and ras cheese respectively (Table, 3). While the percentage of inactivated spores were gradually increased reaching $99.96 \%$; $99.99 \%$ and $99.98 \%$ respectively within $60 \mathrm{hs}$ incubation. 
Table 3

Inactivation percentages (\%)of $\mathrm{Cl}$. perfringens ATCC 13700 in dairy product samples

\begin{tabular}{|c|c|c|c|c|c|c|}
\hline \multirow{2}{*}{ Time(hour) } & \multicolumn{2}{|c|}{ Kareish cheese } & \multicolumn{2}{l|}{ Canned damiatta cheese } & \multicolumn{2}{c|}{ Ras cheese } \\
\cline { 2 - 7 } & Control & Treated & Control & Treated & Control & Treated \\
\hline Zero & 100 & 0 & 100 & 0 & 100 & 0 \\
\hline $\mathbf{6}$ & 23.07 & 76.93 & 18 & 82 & 22.22 & 77.78 \\
\hline $\mathbf{1 2}$ & 8.36 & 91.64 & 9.26 & 90.37 & 10.10 & 89.90 \\
\hline $\mathbf{1 8}$ & 5.66 & 94.34 & 3.92 & 96.37 & 5.54 & 94.46 \\
\hline $\mathbf{2 4}$ & 1.08 & 98.92 & 2.17 & 97.83 & 4.66 & 95.34 \\
\hline $\mathbf{3 6}$ & 0.53 & 99.47 & 0.20 & 99.8 & 0.32 & 99.68 \\
\hline $\mathbf{4 8}$ & 0.12 & 99.88 & 0.02 & 99.97 & 0.03 & 99.97 \\
\hline $\mathbf{6 0}$ & 0.04 & 99.97 & 0.01 & 99.99 & 0.02 & 99.98 \\
\hline
\end{tabular}

\section{Discussion}

Cl. perfringens has been commonly isolated from dairy products collected from the supermarkets allover Egypt by many investigators (El-Bassiony, 1977; Bergere and Cerf, 1978; Shelaih, 1979, Saudi, 1980; El-Boudy, 1985; Sinha \& Sinha, 1986 and Hatab, 1996). Consequently, dairy products could be incriminated in the food poisoning outbreaks especially when inadequate refrigeration was applied. In addition, late fermentation Clostridia (Cl. perfringens, $\mathrm{Cl}$. sporogens and $\mathrm{Cl}$. butyricum) were considered the most dangerous spoilage microorganisms in cheese making, causing blowing for cheese rendering it undesirable to consumer due to formation of off-flavors. Hence, controlling of $\mathrm{Cl}$. perfringens spores in dairy products is one of the challenges facing food hygienists allover the world. Increasing the consumers demand for additives-free dairy products have led to greater interest in the application of natural inhibitory substances like bacteriocin as food bio-preservatives which could replace the use of chemical additives (Vaughan et al., 1994).

In this study, $\mathrm{Cl}$. perfringens was re-isolated from inoculated dairy samples stored at $37^{\circ} \mathrm{C}$. kareish, canned damiatta and Ras cheeses contained nearly $45 \%$ fat, $62 \%$ moisture content and not more than 5\% salt. $\mathrm{Cl}$. perfringens was reported to survive at sodium chloride concentrations up to $6 \%$ which were higher than used in normal fermented foods (Abd-el- 
Rahman, 1972; El-Bassiony, 1975 and Abdel-Hakiem, 1986). In addition, storage temperatures play an important role for growth of $\mathrm{Cl}$.perfringens in dairy product samples. Kramer and Schallehn, (1974) confirmed that dairy products must be stored at temperature below $15^{\circ} \mathrm{C}$ to prevent grows of $\mathrm{Cl}$.perfringens.

The inactivation of $\mathrm{Cl}$. perfringens by Lactobacillius plantarum bacteriocin in different foods contributes to a better understanding of the microbial processes. This of interest due to the wide applications of $L$. plantarum strains as starter cultures for food fermentation (Hugas et al., 1993).

The significant decrease in viable cells count of $C l$. perfringens UG1 in treated dairy product samples by $100 \%$ within $60 \mathrm{hr}$. were related to the anticlostridial activity of plantaricin $\mathrm{UG} 1$ at $37^{\circ} \mathrm{C}$. plantaricin UG1 could be more effective as natural bio-preservative rather than other preservatives due to its inhibitory activity at acidic and neutral pH (Enan et al., 1994). Bacteriocin as a natural bio-preservative was recommended as food preservatives especially against lactic acid bacteria (Nettles and Barefoot, 1993), and more recently it was recommended against $\mathrm{Cl}$. perfringens in a study conducted by Enan (2006). The bacteriocin plantaricin UG1 inactivate $C l$. perfringens within three days of study in vitro and vivo. It could be attributed to bacteriocin effect which alter the tertiary structure of bacterial endospores making inactivated spores (Lopez et al 2003) and killing effects of plantaricin UG1 against the germination of survivors (Enan, 2000).

\section{Conclusion}

Bacteriocin plantaricin UG1 could be used as a food additive and its producer, Lactobacillus plantarum UG1, as starter culture for milk fermentation to prevent the blowing of cheese due to clostridia contamination, without adverse effect on cheese quality. Although the inhibitory effect of bacteriocin plantaricin UG1 against $C l$. perfringens in dairy product samples was confirmed in this study, more investigation may still required to clarify the use of bacteriocin plantaricin UG1 to control food-borne pathogens in dairy products to safe the consumers' health.

\section{Acknowledgment}

My indebtedness to Prof. Dr. G. Enan, professor of food microbiology, King Khalid Military Academy, Sauidi Arabia; and Prof. Dr. Ir. J. Debevere, Charman of Department of Food Technology and Food preservation at university of Gent, Belgium for providing the experimental strains. 


\section{References}

Abdel-Hakiem E.H. (1986): Sanitary condition of milk, fermented milk, kareish cheese and butter manufactured in Assiut Province, MV.Sc. Thesis. Faculty of Vet. Med., Assiut Univeristy, Egypt.

Abdel-Rahman, H.A. (1972): Studies on Egyptian white cheese. M.V.Sc. Thesis Fac. Vet. Med. Cairo University, Egypt.

Bergere, J.L. and Cerf, O. (1978): Spore forming bacteria in heat treated soft cheese. International Dairy Congres, Vol. E.:766.

Bhunia, A.K., Johnoson, M.C. and Ray, B. (1988): Purification, characterization and antimicrobial spectrum of bacteriocin produced by Pediococcus acidilactici. J. Appl. Bacteriol., 65:261-268.

Craven, S.E. and Blankenship, L.C. (1985): Activation and injury of Clostridum perfringens spores by alcohols. Appl.Environ.Microbiol., 50: 249-256.

De Man, J.C., Rogosa, M. and Sharp, M.E. (1960): A medium for the cultivation of lactobacilli. J. Appl. Bacterial, 23:130-138.

Duncan, C.L. and Strong, D.H. (1968): Improved medium for sporulation of Clostridium perfringens. App. Microbiol., 16: 82-89.

El-Bassiony, T.A. (1975): Studies on Kareish cheese in Upper Egypt. M.V.Sc. Thesis Fac. Vet. Med. Assiut Univ. Egypt.

El-Bassiony, T.A. (1977): Incidence of pathogenic microorganisms and viability of some food poisoning bacteria in kariesh cheese during storage. Ph.D. Thesis, Fac. Vet. Med. Assiut, Univ. Egypt.

El-Boudy, A.A. (1985): Studies on spore forming poisoning organisms in milk and some milk products. M.V.Sc. Thesis, Fac. Vet. Med. Alexandria Univ. Egypt.

Enan, G. (2000): Inhibition of B. cereus ATCC 14579 by plantaricin UG1 in vitro and in food. Nahrung/Food, 44: 364-367.

Enan, G. (2006): Inhibition of Clostridium perfringens LMG 11264 in meat samples of chicken, turkey and beef by the Bacteriocin Plantaricin UG1. Intern. J. of Poultry Science 5 (2):195-200.

Enan, G., El-sayed, M.A., El-Essawy, A.A. and Debeveere, J. (1994): Influence of growth medium on Lactobillus plantarum UG1 growth and bacteriocin production. Proceedings of the $7^{\text {th }}$ forum for Applied Biotec. Brugge, Belgium, 2311-2316.

Enan, G., Uyttendaele, M., El-Essawy, A.A. and Debevere, J. (1996): Antibacterial activity of Lactobacilluss plantarum UG1 isolated from dry sausage: characterization, production and bactericidal action of plantaricin UG1 in vitro and in food. International J. Food Microbiol., 30: 189-215.

Enan, G.; Abdel-Salam, H and El-Azouni, I (2004): Partial purification of plantaricin UG1: an anticlostridial bacteriocin produced by L. plantarum UG1, Egypt . J. Microbiol., 9:251-266. 
Garcia, J.C., Limon, J.C. and Heredia, N.L. (2001): Cross protection by heat and cold shock to lethal temperatures in Clostridium perfringens. Brazilian J. Microbiol., 32: 110-112.

Hatab, M.A. (1996): prevalence of clostridia in milk and some dairy products. Ph.D. Thesis. Fac. Vet. Med. Zagazig Univ. Egypt.

Hugas, M; Garriga, M.; Aymerich, T. and Monfort, J.M. (1993): Biochemical characterization of lactobacilli from dry fermented sausages. Int. J. Food Microbiol. 18: 107-113.

Kramer, J. and Schallehn, G. (1974): Effect of enterocin of Clostridium perfringens and Clostridum septimum. Zentralbl Bakterial., 1: 105-113.

Lopez, P.T.; Riog, I.X. and Guamis, B. (2003): Inactivation of Bacillus cereus endospores in cheese by high hydrostatic pressure with addition of nisin or lysozyme. J. Dairy Sci., 88: 3075-3081.

Martel, A.; Devrise, L.A.; Cauwverts, K.; De Gussem, K.; Decostere, A. and Haesebrouck, F. (2004): Susceptibility of $\mathrm{Cl}$. perfringens strains from broiler chickens to antibiotics anticoccidials. Avain., Pathol., 1: 3-7.

Nettles, C.G. and Barefoot, S.F.(1993): Biochemical and genetic characteristics of bacteriocin of food associated lactic acid bacteria. J. Food Prot., 56: 338-358.

Rhodehamel, J.E. and Harmon, S.M. (2006): Clostridum perfringens. Bacteriological analytical manual on line, pp:1-6.

Saudi, A.M. (1980): Microbiological studies in food poisoning microorganisms in some market dairy products. Ph.D. Thesis. Fac. Vet. Med. Cairo Univ., Egypt.

Shelaih, M.A. (1979): Microbiological studies on Egyptian soft cheese. Ph.D. Thesis. Fac. Vet. Med. Cairo Univ. Egypt.

Sinha, R.N. and Sinha, P.R. (1986): Incidence of clostridia with reference to dairy processing. J. Food Sci. and Tech., India, 25:2,101-102.

Steele, F.M. and Wright, K.H. (2001): Cooling rate effect on outgrowth of Clostridum perfringens in cooked, ready-t0-eat turkey breast roasts. Poult. Sci., 6:813-816.

Teo, A.Y. and Tan, H.M. (2005): Inhibition of Clostridium perfringens by a noval strain of B. subtidis isolated from gastrointestinal tracts of healthy chickens. Appl. Environ. Microbiol., 71:4185-4190.

Vaughan, E.E.; Caplice, E.; Looney, R.; O'Rourke, N.; Conveney, H.; Daly, C. and Fitzgerald, G.F.(1994): Isolation from food sources of lactic acid bacteria that produce antimicrobials. J. Appl. Bacteriol., 76: 118-123.

Wise, M.G. and Sirgusa, G.R. (2005): Quantitative detection of Clostridium perfringens in the broiler foil gastrointestinal tract by real time PCR. Appl. Environ. Microbiol., 71: 3911-3961. 